\title{
CT findings in type IV hiatus hernia involving the pancreas
}

\author{
Maged Nassef Abdalla Fam, Khaled Mostafa Elgharib Attia
}

Kuwait Hospital, SharjahMinistry of Health, Sharjah, UAE

\section{Correspondence to} Dr Maged Nassef Abdalla Fam, maged-fam@hotmail.com

Accepted 29 January 2016

\section{DESCRIPTION}

A 46-year-old man presented to the emergency room with chest pain of 45 min duration associated with dyspnoea and sweating. Clinical assessment, biochemistry and ECG pointed to stable angina pectoris as the diagnosis. However, a chest radiograph obtained during his initial evaluation showed an intrathoracic lucent, air filled and lesion (figure 1).

This lesion was further evaluated by a chest and abdominal contrast-enhanced CT scan, which revealed a distended, totally herniated intrathoracic stomach along with peritoneal fat and distal body and tail of pancreas (figures 2 and 3). These findings were in keeping with type IV hiatus hernia.

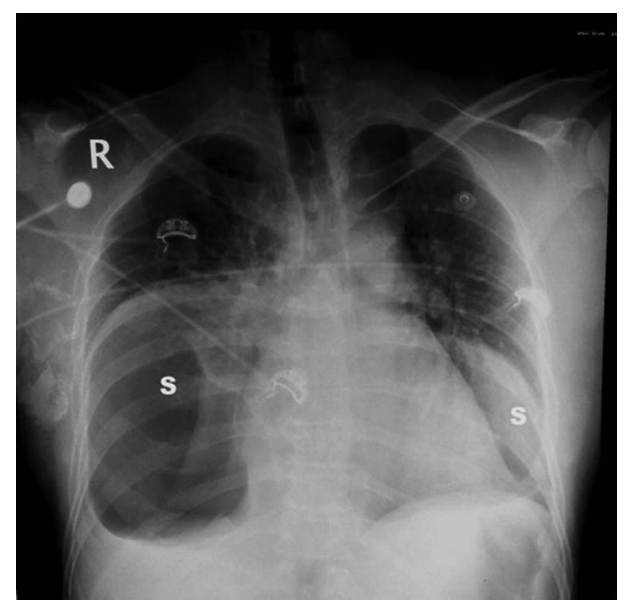

Figure 1 Frontal chest radiograph showing a lucent, air-filled structure $(\mathrm{S})$ seen within both thoracic compartments. The carina is splayed.

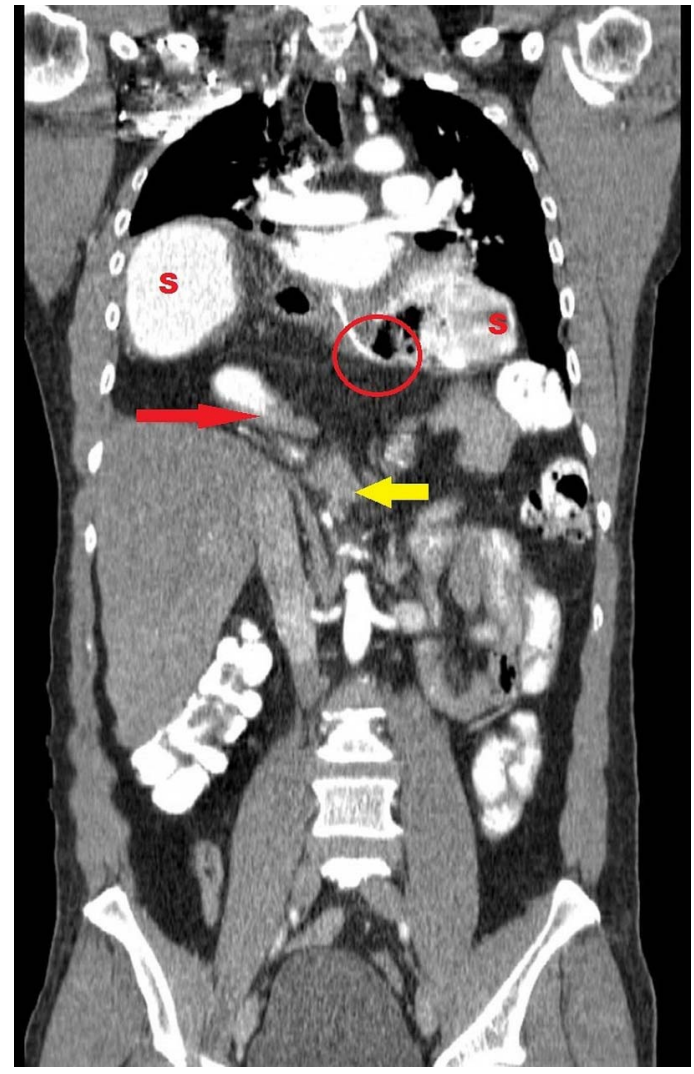

Figure 3 Contrast-enhanced CT (oral and intravenous), coronal reformatted image, showing the whole stomach and gastro-oesophageal junction herniating to the thoracic cavity along with an abnormally located pancreatic body. S, stomach; red circle, gastro-oesophageal junction; red arrow, pylorus; yellow arrow, pancreatic body.

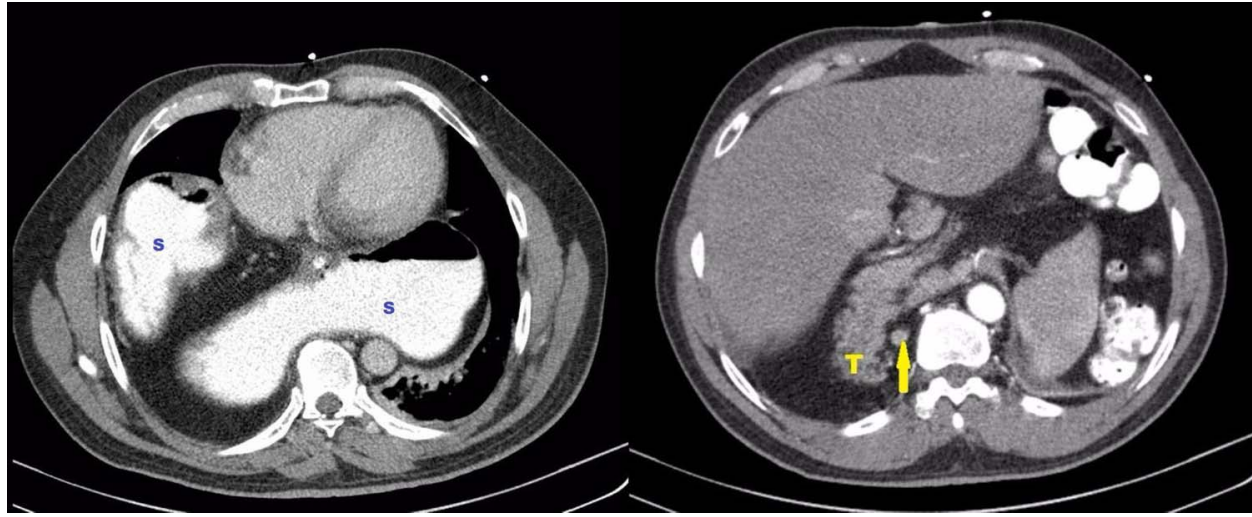

Figure 2 Contrast-enhanced CT (oral and intravenous), axial sections, showing the stomach, pancreatic tail and splenic vein ascending to the thoracic cavity. S, stomach; T, pancreatic tail; yellow arrow, splenic vein. 


\section{Learning points}

- It is rare for the pancreas to be involved in type IV hiatus hernia.

- Type IV hiatus hernia can be asymptomatic.

- Surgical correction may not be indicated for asymptomatic patients.

Since there was no significant chronic gastrointestinal tract-related symptoms and since the patient improved after antiischaemic therapy, a decision was made for conservative treatment regarding this incidental uncomplicated hiatus hernia.

Hiatus hernia is classified into four types, ${ }^{1}$ with type IV being the only type where other abdominal organs, such as the colon, small bowel or pancreas, accompany the stomach into the thorax. Type IV hiatus hernia is uncommon, representing 5-7\% of all hiatus hernias. ${ }^{2}$

Involvement of the pancreas as a part of the hernia is a very rare occurrence. Patients may be asymptomatic or present any of the typical or atypical symptoms seen in the other three hernia types, such as dysphagia, regurgitation or chest pain. ${ }^{3}$

According to the Society of American Gastrointestinal and Endoscopic Surgeons' 2013 guidelines: ${ }^{1}$ routine elective repair of completely asymptomatic hernias may not always be indicated. Consideration for surgery should include the patient's age and comorbidities.

Contributors KMEA contributed to the discussion and findings sections.

Competing interests None declared.

Patient consent Obtained.

Provenance and peer review Not commissioned; externally peer reviewed.

\section{REFERENCES}

1 Kohn GP, Price RR, Demeester SR, et al. Guidelines for the management of hiatal hernia. http://www.sages.org/publications/guidelines/guidelines-for-the-managementof-hiatal-hernia (accessed 20 Oct 2015)

2 Grushka JR, Grenon SM, Ferri LE. A type IV paraesophageal hernia containing a volvulized sigmoid colon. Dis Esophagus 2008;21:94-6.

3 Davis SS Jr. Current controversies in paraesophageal hernia repair. Surg Clin North Am 2008;88:959-78.

Copyright 2016 BMJ Publishing Group. All rights reserved. For permission to reuse any of this content visit http://group.bmj.com/group/rights-licensing/permissions.

BMJ Case Report Fellows may re-use this article for personal use and teaching without any further permission.

Become a Fellow of BMJ Case Reports today and you can:

- Submit as many cases as you like

- Enjoy fast sympathetic peer review and rapid publication of accepted articles

- Access all the published articles

- Re-use any of the published material for personal use and teaching without further permission

For information on Institutional Fellowships contact consortiasales@bmjgroup.com

Visit casereports.bmj.com for more articles like this and to become a Fellow 